\title{
Vaccine production, national security anxieties and the unstable state in nineteenth- and twentieth-century Mexico
}

\author{
Ana María Carrillo
}

\section{Introduction}

Since pre-Columbian times, Mexico has experienced notable periods of progress in science and technology. Political, economic and social problems have, however, often interrupted these developments, thus the country has been forced to rebuild its science and technology capacity time and time again. Since 1821, when the country began its independent life, Mexican government investment in education and research has been essential for modern science to flourish. In its search for self-determination, the Mexican state has employed science both to legitimise itself and to serve society.

This chapter deals with the development and production of vaccines in Mexico from the last third of the nineteenth century to 1989, when the erosion of this sector began. Along with discussing Mexican physicians' reception of discoveries in microbiology and immunology, it highlights the existence of a network of relationships between Mexican institutions and others around the world. The chapter shows that vaccine development and production did not follow a constant ascendant path, but that it also suffered declines and regressions. It describes the field's achievements and limitations and reveals its relationships with the political, economic and social conditions of the country in different historical moments. Finally, the chapter evaluates the importance of attaining national self-sufficiency in vaccine development and production for the building of the state in preand post-revolutionary Mexico, and seeks to provide some answers 
to the questions of how and why the erosion of this strategic field occurred.

For three centuries (1521-1821) Mexico - then, New Spain - was part of the Spanish Empire. In New Spain, the arrival of modern science late in the colonial period was mediated both by the existence of a selftaught community of enlightened individuals interested in progressing towards applied science, and the imperialist economic reform of the Spanish state in the eighteenth century, which created institutions in order to offer scientific instruction, improve economic exploitation and better local conditions. ${ }^{1}$

It was in this context that vaccination against smallpox was officially introduced to New Spain in 1804 by the Spanish Royal Philanthropic Expedition - supported by King Charles IV of Spain and led by Francisco Javier de Balmis - though the vaccine had in fact arrived earlier. ${ }^{2}$ That year, officials established the first vaccination centre in Mexico City; according to Miguel E. Bustamante - epidemiologist and historian - this signalled the beginning of governmental action in the area of preventive medicine. ${ }^{3}$

The War of Independence (1810-21) affected all national institutions, and medical practice was no exception. After 1821, the formation of the modern state began, which included attempts to control economic processes and create a strong political system. Mexican independent governments considered science a matter of public interest, and utilised it to build a national culture in a context of the increasing secularisation of society. ${ }^{4}$

In the case of smallpox, for example, for more than a hundred years only five people managed the vaccine in Mexico, so that its purity was guaranteed. ${ }^{5}$ Public health officials administered the vaccine in areas as remote as Texas $^{6}$ - which was part of Mexican territory until 1836 - but service was not always continuous because between 1810 and 1876 the country suffered constant political instability.

In addition to the War of Independence, Mexico underwent two French interventions (1838-39 and 1862-67), the Mexican-America War - which began in 1846 and ended two years later, culminating in Mexico's loss of more than half of its territory to the United States - as well as indigenous groups' insurrections and struggles between liberals and conservatives. For all these reasons, in this period at least fifty smallpox epidemics occurred in the country. ${ }^{7}$ 


\section{The beginning of vaccine production}

A relative pacification of the country arrived with the authoritarian regime of Porfirio Díaz (1876-1910), one marked by the modernisation of society and the economy and by a growing concentration of federal political power. Strong central government brought improvements in mining, industry and also public health. Vaccination laws were part of this health policy, and by the end of the Díaz regime smallpox vaccination was mandatory in most states in the Mexican republic. ${ }^{8}$ But, as Stern and Markel have stated, 'vaccines are powerful medical interventions that induce powerful biological, social and cultural reactions', including insurrections. ${ }^{9}$ While Mexico does not appear to have experienced any medical movements opposed to smallpox vaccination, a century after its introduction there was still public opposition. Perhaps the most significant case was in the state of Oaxaca, where compulsory vaccination was established in 1903, but five years later a popular rebellion achieved its cancellation. ${ }^{10}$

Vaccination in this period was not limited to the prevention of smallpox. Several nineteenth-century Mexican physicians were in direct contact with international scientists, and through them the introduction of bacteriological thinking and practices took place in Mexico in the late nineteenth and early twentieth centuries. Eduardo Liceaga president of the Superior Board of Health - visited the Pasteur Institute in France in 1888, was given personal instruction, and learned to prepare the rabies vaccine. Early that year, he inoculated a Mexican boy ${ }^{11}$ and established the Anti-Rabies Preventive Inoculation Service, as a branch of the Superior Board of Health. ${ }^{12}$ From 1888 to 1910, the board administered 11,177 inoculations - with only thirteen deaths recorded among the recipients. ${ }^{13}$ By 1909, five states of the Mexican republic had created anti-rabies centres.

In 1895, the Pathological Anatomy Museum was founded. Upon applying for its creation, Rafael Lavista, its first director, assured President Díaz that as well as demonstrating to visitors to the Second PanAmerican Medical Congress (to be held in Mexico two years later) that science was being cultivated in the country, it was also required for the study of the symptoms manifested by diseases modified by climate, elevation and other characteristics peculiar to Mexico. Almost from the beginning, the museum had a bacteriology section, which continued 
working after 1899 when the Pathological Anatomy Museum was transformed into the National Pathology Institute. ${ }^{14}$

At the end of 1902, a plague epidemic affected some ports and cities in northwest Mexico. The sanitary campaign organised by the Superior Board of Health to combat the outbreak was a watershed moment, signalling the beginning of modern public health in Mexico.

This was the first sanitary campaign in the country in which a state government ceded public health authority to the federal government, and also the first to be based on the emerging scientific fields of microbiology, immunology, tropical medicine and epidemiology. The sanitary bureaucracy sought to control the outbreak through persuasive methods, but relied mostly on coercion, including a mandatory vaccine policy that generated various forms of popular resistance. ${ }^{15} \mathrm{M}$. J. Rosenau, Head of the Hygiene Laboratory of the Marine Hospital Service of the United States, sent two cultures of Bacillus pestis to Mexico free of charge, ${ }^{16}$ and the Bacteriology Section of the National Pathology Institute produced and certified doses of the Haffkine and Besredka vaccines, the latter of which underwent its first extensive testing in Mexico (the Haffkine vaccine was first tested in India). ${ }^{17}$ The institute also prepared sera for curative purposes, and exported some doses of the Besredka vaccine to Chile and El Salvador.

The Bacteriology Section played such an important role in the sanitary campaign against plague that, along with the Medical Chemistry Section, it was separated from the Pathology Institute in 1905 to create the National Bacteriology Institute. The new institute was made up of sections for bacteriology, serum preparation, biological chemistry and veterinary medicine. ${ }^{18}$ As similar institutes around the world, it combined research with biological production. In addition to plague vaccines, the institute produced tetanus, diphtheria, dysentery, gangrene and pneumococcus sera, and supplied these to public health authorities. ${ }^{19}$ Early in the twentieth century, the Superior Board of Health, with the support of the National Bacteriology Institute, established bacteriology stations in some ports, in order to diagnose cases of plague and cholera and vaccinate against both illnesses; in the case of cholera, with Jaume Ferran's vaccine. ${ }^{20}$ Smallpox and rabies vaccines were excluded from the Bacteriology Institute's responsibilities, as the Superior Board of Health produced them itself. 
In 1900, life expectancy in Mexico was only 25 years, and infant mortality was 288 per 1,000 live births. Smallpox, measles, pertussis (whooping cough) and diphtheria were common among children, and the two leading causes of death were diarrhoeal and respiratory diseases, preceded almost always by malnutrition. ${ }^{21}$ At the time, some countries, particularly the United States, threatened Mexico with exclusionary quarantines due to its infectious disease burden, and pushed it - along with other countries - to adopt hygienic measures in its ports and in other areas strategic for international trade. In order to protect commercial activities, the Mexican Superior Board of Health actively fought plague outbreaks when they arrived at the country's ports, and prioritised the campaign against yellow fever. ${ }^{22}$ However, they also organised campaigns against malaria, tuberculosis and syphilis, which were endemic in Mexico.

At the time, specialisation in bacteriology was, generally speaking, only available in some foreign laboratories, though some individuals were trained in Mexico under the direction of a bacteriologist, Mexican or otherwise. Much depended on the individual training of young Mexican scientists or on the interest of foreign bacteriologists on conditions in Mexico; as a result no country dominated and French, German and American influences flowed into Mexico by singular routes. French influence was strong, both because of the fact that several French scientists were working in Mexico, but also more commonly because Mexican physicians had received training there.

The first head of the National Bacteriology Institute and the pioneer of microbiology in Mexico, Ángel Gaviño, had been trained by Roux and Duclaux at the Pasteur Institute, ${ }^{23}$ while Joseph Girard, a French bacteriologist who interned at the Pasteur Institute, worked from 1906 to 1913 as the assistant director of the Laboratory of the National Bacteriology Institute in Mexico. ${ }^{24}$ But that period also saw a great diversification of influences. Manuel Toussaint - who was for a time in charge of both histological and bacteriological work at the Pathological Anatomy Museum, and would later serve as the head of the National Pathology Institute - studied for several years in Germany. ${ }^{25}$ Most of Gaviño's scientific training had also taken place in Germany, and he went to the United States and Canada several times to attend American Public Health Association meetings. Octaviano González Fabela - bacteriologist of the Superior Board of Health - took courses at the 
universities of Harvard and Pennsylvania, and during the revolutionary years he studied in Bern, Switzerland. ${ }^{26}$ A US scientist, Howard Taylor Ricketts - professor at the universities of Pennsylvania and Chicago died in Mexico while conducting research on typhus at the National Bacteriology Institute with his colleague Russell M. Wilder. ${ }^{27}$ Despite all these international influences, the National Bacteriology Institute and all Mexican scientific institutions were financially and therefore also scientifically, independent of any foreign country.

\section{The revolution and the beginnings of national reconstruction}

The research and public health programme active at the beginning of the twentieth century was abruptly interrupted by the revolution that broke out in Mexico in 1910, as peasants throughout the country rose up against poor living conditions and the lack of local democracy. The civil war lasted a decade, during which most sanitary campaigns were abandoned and many scientific institutions, among them the National Pathology Institute, were forced to close. The revolutionary governments that ruled during this time not only ceased to support basic medical sciences, but actively opposed to them and favoured applied science. $^{28}$

The National Bacteriology Institute survived for a few more years, but in 1913 it too suspended all original research and one year later interrupted its production of sera and vaccines. In 1913 and 1914, Gaviño reported on several occasions that budget constraints and the lack of test animals had made further research on typhus and diphtheria impossible. In 1914, he was fired from his position as director of the Institute. This matter involved both jealousy between colleagues and political conflict, because Gaviño had collaborated with the government of Victoriano Huerta, who had risen to power after a coup d'état against the revolutionary government of Madero. After Huerta was defeated, Gaviño was sacked by the new revolutionary government when González-Fabela stated - after a one-hour visit to the Institute - that he distrusted domestic sera. At the time, Gaviño warned the minister of Government of the danger of eliminating the stock of national sera, including the significant holdings stored at the National Bacteriology Institute, and argued that the country needed them especially during a period when Europe was at war and sera prices were 
exorbitant. He further asserted that the sera of the National Bacteriological Institute enjoyed great prestige, both inside the country and beyond its borders. ${ }^{29}$

When the revolutionary state finally established a degree of stability, it sought to centralise sanitary activities, professionalise the public health sector and reorganise vaccine production. In 1918, Gaviño was called once again to direct the National Bacteriological Institute, which by that time was producing only smallpox vaccine. Yet another plague epidemic affected various states of the republic in 1920, and despite the terrible conditions that reined at the institute, Gaviño managed to extinguish the epidemic by providing thousands of doses of both sera and vaccines. ${ }^{30}$ In 1921, the Rockefeller Foundation began to play an important role in public health in Mexico. It taught health workers at two training stations established in the country, and sent sixty-eight Mexican fellows to North American universities, most of whom later occupied high-ranking posts in the Mexican federal public health bureaucracy or headed research institutes. ${ }^{31}$

Following the prolonged period of civil armed struggle, the process of state reconstruction included the creation of institutions, among them some related to the health sector. Though the civil war profoundly affected the National Bacteriology Institute, in 1920 it was reorganised as the Institute of Hygiene, an offshoot of the Public Health Department - which at the end of the revolution had replaced the Superior Board of Health - and was engaged in both research and the production of sera and vaccines. In 1925, only four years after Albert Calmette and Camille Guéran had prepared a vaccine for tuberculosis (the BCG) in France, and the first clinical trial with Bacillus Calmette-Guérin took place, Fernando Ocaranza - then head of the Institute of Hygiene received strains of attenuated Bacillus from Calmette, and in 1931 began production of the BCG in Mexico. ${ }^{32}$ This was despite the fact that in 1929, over a hundred vaccinated children died in a German town due to accidental contamination of the vaccine with a virulent strain. ${ }^{33}$

Both Hans Zinsser (Harvard University) and Herman Mooser (University of Zurich, who also worked at Harvard) supported the participation of North American universities in Mexican medicine. Their Mexican disciples, Maximiliano Ruiz Castañeda and Gerardo Varela, were awarded fellowships by the Rockefeller Foundation and opened the door to post-Pasteurian bacteriology in Mexico. ${ }^{34}$ Ruiz Castañeda 
had studied microbiology at the University of Paris and the Pasteur Institute between 1924 and 1925. He then travelled to the United States, where he discovered, together with Mooser and Zinsser, that rats serve as a reservoir for murine typhus, and that the vehicle of transmission is the flea. In the early 1930s, Zinsser and Ruiz Castañeda developed a serum that was tested on hospitalised patients and the general population in times of epidemics, as well as a vaccine against typhus. ${ }^{35}$

\section{Vaccines: a means to an end}

The true pacification of Mexico took place under the government of Lázaro Cárdenas (1934-40), which included a social project designed to fulfil the promises that the Revolution had made to the peasants and workers who had participated in it. Cárdenas granted 49,605,673 acres of fertile land to one million peasants, and accompanied this measure with credits, as well as water, and educational and medical services. ${ }^{36}$

Cárdenas' regime brought about the creation of the Institute of Public Health and Tropical Diseases, which was at the forefront in integrating research teams in protozoology, helminthology, entomology, anatomo-pathology, bacteriology, pharmacology, chemistry, epidemiology and statistics. For almost two decades, the Institute of Hygiene had carried out basic research, but this research ceased when the Institute of Public Health and Tropical Diseases was established. However, the Institute of Hygiene continued producing vaccines and sera, and extended its laboratories to satisfy the demand for biological products. ${ }^{37}$ The Anti-Rabies Institute of Mexico survived until 1938, the year in which Pasteur's classical method was replaced by that of Sample, and rabies vaccine production was entrusted to the Institute of Hygiene. $^{38}$

Other centres were also conducting vaccine research and development. Ruiz Castañeda returned to Mexico at the end of the 1930s, founded the Experimental Laboratory of Immunology at the General Hospital of Mexico City, and with his team developed another vaccine against typhus, this one based on Ricketsia prowasekii attenuated in rats's lungs. To investigate the value of the vaccine, medical experimentation was carried out on prisoners and general paralytics, while the Germans repeated the experiments on Jews in the Warsaw ghetto during the Second World War. ${ }^{39}$ The ethical aspects of conducting medical 
experiments at concentration camps have been analysed elsewhere, ${ }^{40}$ but these episodes of clinical experimentation in Mexico should be examined as well. This particular typhus vaccine was, however, destined to be forgotten, because scientists began to utilise DDT to destroy lice and fleas, and antibiotics to treat clinical forms of the disease. ${ }^{41}$

In 1943, the American Academy of Paediatrics approved for routine use the pertussis vaccine - developed by Pearl Kendrick and her partner Grace Eldering at the Michigan Department of Health Laboratory and a year later the American Medical Academy recommended its use. According to Shapiro-Shapin, Kendrick and Eldering shared their vaccines, plates, cultures and research with scientists around the world, and helped them to establish vaccine programmes. ${ }^{42}$ This was also the case in Mexico, where pertussis vaccine production began as early as 1940 under the supervision of Dr Kendrick. ${ }^{43}$ In general, vaccine production remained at low levels, in accordance with the demands of health services; but in the case of the pertussis vaccine, demand grew rapidly, so production had to as well: in 1940, the laboratory produced $19,365,000 \mathrm{ml}$, and in $1944,215,545,000 \mathrm{ml}$, to be used in large-scale vaccination campaigns. ${ }^{44}$

In 1943, the Public Health Department (which was responsible for public health activities) amalgamated with the Ministry of Welfare (which had been in charge of public hospitals), to form the Ministry of Health and Welfare. The Laboratory of the Pharmaceutical Industry, previously part of the Ministry of Welfare, was incorporated into the Institute of Hygiene, but closed when the National Chemical Pharmaceutical Industry was born. ${ }^{45}$

Cárdenas had proposed to combat the causes of infant mortality, as well as the roots of epidemic and endemic diseases that plagued the population, by improving diet and housing and emphasising the importance of preventive medicine, but the governments that followed gradually abandoned these projects and changed the focus to curative medicine. ${ }^{46}$ This was most likely one of the reasons why the number of smallpox cases increased between 1943 and 1945, presenting a challenge for Mexican health workers.

Mexican sanitary authorities reorganised the Anti-Smallpox Campaign in 1950, and brigades spread out across the country. Scientists had obtained the technique for producing glycerinated pulp through the Research Institute in Lagos, Nigeria, and had managed to increase 
and conserve its potency. Nevertheless, at the request of the PanAmerican Health Organization (PAHO), they agreed to conduct experiments in Mexico with dried smallpox lymph. The last case of the illness in the country was reported in February 1951. On 16 June 1952, the World Health Organization (WHO) declared that smallpox had been officially eradicated from Mexico, twenty-six years before it was totally eradicated worldwide. Vaccine production and smallpox vaccination nevertheless continued until the end of the 1970s. ${ }^{47}$ In 1982, at the suggestion of Dr Arita - chief of the WHO Smallpox Eradication Unit - Mexican sanitary authorities destroyed their remaining stocks of the virus. ${ }^{48}$

Other vaccines experienced interrupted development in Mexico. The Campaign against Tuberculosis had included BCG vaccination since the 1930s, but in 1950 several newborn babies, vaccinated with oral BCG during the first ten days of life, died of generalised tuberculosis. Though physicians knew that the intravenous vaccination was safer, they opted for the oral vaccine because parents accepted it more easily. The BCG Laboratory's director, specialists, and even the mission chief in Mexico for the International Campaign against Tuberculosis deliberated the subject. After thorough research, the Consultant and Technical Body of the BCG of the Ministry of Health and Welfare reported that all of the deceased babies had been breastfed and none had a family history of tuberculosis, and thus concluded that the deaths were due to the vaccine, adding that: 'The magnitude of the disaster caused by the oral administered BCG in Mexico still needs to be clarified. ${ }^{49}$ They pointed out that infant mortality had significantly risen in Mexico City just after the introduction of oral BCG vaccination, and a newspaper campaign against the vaccine drew on evidence from independent physicians and sanitary personnel who were opposed to the oral BCG. Oral vaccination was suspended, as it was in most countries at the time, but the controversy also affected intravenous vaccination. Those opposed to oral BCG suggested returning to sanitary methods of control sanctioned by experience, and it took ten years for tuberculosis vaccination advocates to be able to bring vaccination back to Mexico. ${ }^{50}$

In 1951, the Institute of Hygiene informed the Ministry of Health and Welfare that it was possible to produce the yellow fever vaccine in Mexico, though a laboratory and equipment would be required. $\mathrm{Dr}$ 
Rake of Squib Laboratories in the United States had provided them with plans for the installation of such a laboratory, ${ }^{51}$ which was finally developed, ${ }^{52}$ though there were periods in which the country did not produce the vaccine.

As mentioned previously, scientists had produced the simple pertussis vaccine since 1940. Eight years later, they achieved a successful combination with diphtheria toxoid, and in 1954 it finally became possible to include the tetanus toxoid. ${ }^{53}$ Armed with this combination vaccine, DPT, in 1960 Mexican health authorities began massive vaccination campaigns.

The population had received news of the first poliomyelitis epidemics in Mexico with enormous anxiety. In 1953 - the year of one of the most severe epidemics - the National Campaign against Poliomyelitis was declared in the national interest and on the same day the National Committee for the Fight against Poliomyelitis was established. ${ }^{54}$ The problem of poliomyelitis could only be solved by preventive vaccination, since treatment capacity was severely limited. In 1960, for example, the Children's Hospital of Mexico had only a dozen beds and a dozen iron lungs for sick children, as well as a department of rehabilitation and physical therapy, at a time when hundreds of children and adults were already suffering the paralytic effects of the disease, and hundreds more would be added every year. ${ }^{55}$

In April 1955, when the Francis Report declared Jonas E. Salk's 'killed or inactivated' polio vaccine (IPV) safe and efficacious, it was considered timely to begin production in Mexico. ${ }^{56}$ The general director of the Chemical Pharmaceutical Industry and the Centre for the Study of Poliomyelitis - a private group formed to support research and fight the illness - promoted the commencement of vaccine production in Mexico, funded by the Ministry of Health and Welfare and the National Institute for Child Welfare. In 1956, the National Chemical Pharmaceutical Industry produced the first poliomyelitis vaccine, following the methods proposed by Salk and his collaborators. ${ }^{57}$ After two years of vaccination and the application of 1,055,229 doses, Mexican sanitary authorities stated that the vaccine prepared in Mexico was effective in 80 per cent of cases. ${ }^{58}$

Studies with the Sabin 'weakened or attenuated' oral polio vaccine (OPV) began in Mexico in 1957. The vaccine was tested first on orphan children housed in an orphanage, then with children in public day care 
centres and poor communities, and finally in children from the upper social classes. For a time, both vaccines were applied simultaneously due to the need to finish the series initiated with the Salk vaccine, ${ }^{59}$ but health authorities eventually decided to replace the Salk vaccine with the Sabin vaccine. After that, doctors only used the oral vaccine, on the recommendation of the WHO and - as Stuart Blume has shown - due to considerations that were more practical and economic than scientific. ${ }^{60}$ In 1960, the National Institute of Virology was established to make epidemiological diagnoses of illnesses caused by viruses. By 1962, the Sabin vaccine was being produced in Mexico under the supervision of Sabin himself. This is when mass vaccination really began in Mexico. ${ }^{61}$

Though there were difficulties with the production of various vaccines, the most challenging for Mexican scientists was the polio vaccine, and on several occasions Mexico lost and recovered its licence to produce it. It was revoked, for example, in 1970 because virulence tests were not satisfactory, according to the WHO adviser Milan V. Milošević. But production commenced again in 1977 under the aegis of the WHO. After visiting the Mexican National Institute of Virology in 1979, Albert Sabin wrote to Frank T. Perkins - chief of biologics at the $\mathrm{WHO}$ - and to Charles Cockburn - also from the WHO - stating: 'If I were still the official assessor, I would certainly approve this lot of [polio] vaccine. ${ }^{32}$

The potential risks of the OPV were soon discovered, and in the end scientists had to recognise that some cases of polio were related to vaccination, ${ }^{63}$ which is why, after analysing cases in the UK, the Netherlands and West Germany, Lindner and Blume asked themselves whether scientific and epidemiological data determine vaccine policy or, on the contrary, scientific, epidemiological and economic data are subject to construction and reconstruction by political actors. ${ }^{64}$ In Mexico, sanitary authorities only began to switch to IPV at the beginning of 2007.

\section{Crisis, reorganisation and erosion of national capacity in vaccine development}

Advances in therapeutics in the mid-twentieth century and especially the discovery of penicillin gave rise to the generalised opinion that chemotherapy and the antibiotic treatment of infectious diseases were 
so effective that they had made the utilisation of immune-prophylactic measures unnecessary. This notion resulted in decreased support from the private sector and even government entities for institutes or laboratories producing vaccines. These institutions suffered a progressive deterioration as a result. This abandonment came to be felt at the Pasteur Institute in France, and at the Latin American institutes that followed its leadership. ${ }^{65}$

In Mexico, the Institute of Hygiene reflected this abandonment most dramatically, as in 1970 an accident with fatal consequences forced it to temporarily interrupt activities: early that year many children died after being immunised with DPT. Colima, on the Pacific coast, was one of the states most severely affected. At first, sanitary authorities thought it was sabotage, but later it turned out that the problem lay in the institute's procedures. Investigators from the Institute of Hygiene discovered active clostridium tetani (the causative agent of tetanus) in the beakers and test tubes used for the production of the DPT vaccine; a batch of non-detoxified toxin had been mixed in with the vaccine. This contaminated vaccine batch had also been used in the offices of the Civil Registry in Mexico City, where it caused seventy-five deaths. The head of production at the Institute of Hygiene would later declare that it was not a case of negligence, but was due to the lack of material, equipment and adequate installations that she had previously reported to her superiors, in a place where no expense or resource should be spared. $^{66}$

The investigation of the incident was entrusted to the veteran bacteriologist Gerardo Varela, as well as to the head of the Department of Microbiology of the Faculty of Medicine of the National Autonomous University of Mexico, and the dean of the National School of Biological Sciences, at the National Polytechnic Institute. They concluded that there were profound problems at the Institute of Hygiene, such as the reutilisation of animals that had survived other tests, a lack of discipline with respect to international norms of control, dependence on the control laboratory of the institute's production department, which constrained its independence, and lack of capacity on the part of administrative personnel.

The Institute of Hygiene was temporarily closed for reorganisation. ${ }^{67}$ This reorganisation coincided with a worldwide reconsideration of the utility of immune-prophylaxis, and with regional projects by the PAHO 
and others by the WHO. In Mexico, the reorganisation included aid in obtaining strains through agreements with producing laboratories. In addition, staff underwent training, either travelling to international centres or receiving leading scientists at Mexican institutions (frequently with WHO or PAHO support). Help also came in the form of the standardisation of biological products, as well as the implementation of external control of domestically produced vaccines and sera.

Many foreign scientists and institutions collaborated with Mexicans and advised them, such as Tatsuichiro Hashimoto in a new BCG laboratory, and Frank T. Perkins in the production of viral vaccines, particularly against poliomyelitis. The Institute of Immunology of Zagreb provided the Edmonston-Zagrev strain for the production of measles vaccine, and Dr Drago Ikić - the institute's head - advised on the components of DPT. In addition, Jacques Laiuthud of the Institut Mérieux (Lyon, France) helped create a new section of blood derivatives, and Eduardo Fuenzalida aided in the production of a rabies vaccine through an accord with the Bacteriological Laboratory of Chile. Other international institutions that collaborated with Mexico at the time were the Serum Institute of Copenhagen, the Sclavo Laboratories of Siena, the National Institute for Biological Standardisation and Control of London, and the Wellcome Laboratories of the UK. ${ }^{68}$ Between 1983 and 1989, thirty experts from the Pasteur Institute in France, the WHO, the PAHO, the Centers for Disease Control and Prevention, the Food and Drug Administration, and the National Institutes of Health of the United States, visited Mexican institutions to advise on technical activities. There were also reciprocal visits with Colombia, Peru, Chile, Argentina and Brazil. ${ }^{69}$

The Institute of Hygiene had three main functions: production of vaccines and sera, for both national consumption and export; certification of all biological products in accordance with WHO norms; and experimentation with new techniques and methods for the production and administration of biological products. The Institute of Virology, meanwhile, became a laboratory for viral vaccine production against poliomyelitis, measles and rabies. The Reagents Central Laboratory was created. ${ }^{70}$ A decade later, the Institute of Hygiene, the Institute of Virology, and the Central Laboratory were all grouped together as the General Management of Biologics and Reagents, which became virtually the sole producer of biological products in the country. 
In the late 1980s, Mexico was the only Latin American country to produce all of the vaccines included in the United Nations Children's Fund (UNICEF) Extended Vaccination Programme (tuberculosis, diphtheria, pertussis, tetanus, poliomyelitis and measles), as well as human and canine rabies and typhoid fever vaccines, and others in the field of veterinary medicine (a total of twenty-five products). ${ }^{71}$ The Mexican Ministry of Health confirmed that Mexico was also the only developing country that had the equipment, technology and human resources required to produce vaccines against poliomyelitis that were approved by the WHO. The vaccine against measles was produced at the National Institute of Virology, with a methodology first partly, and then wholly, developed there. While the internationally recognised technique required the use of chicken embryos, the methodology developed in Mexico utilised human diploid cells as the substrate, inoculated with a previously adapted vaccine strain of the Edmonton-Zagrev virus. $^{72}$ In 1979, the General Management of Biologics and Reagents was designated by the PAHO as a Regional Centre of Reference for Latin America. As such, it evaluated vaccine lots from twelve countries: Argentina, Brazil, Costa Rica, Chile, El Salvador, Guatemala, Honduras, Nicaragua, Panama, Peru, Dominican Republic and Uruguay, and provided technological support to them all. $^{73}$

Mexico had therefore achieved self-sufficiency in vaccine production, control, storage and distribution, except in the case of the poliomyelitis vaccine, whose production did not always fulfil national demand, and by the end of the 1980s was exporting biological products (including vaccines, mainly for rabies) to fifteen countries in the Caribbean and Central and South America. Domestic vaccine production was a political priority, because politicians saw that imports were expensive and also because national security dictated protecting public health. 'Artisanal' procedures for making vaccines were replaced by industrial methods of production, for which Mexican as well as Dutch manufacturers supplied the needed equipment. In 1983, the Mexican government launched National Vaccination Days, and shortly afterwards it introduced National Vaccination Weeks; these eventually evolved into the nationwide Universal Vaccination Programme. ${ }^{74}$

In 1989, health officials began to compare public and private vaccine production. For some, like Garza Ramos, the former responded to the needs of public health programmes, while the latter obeyed commercial 
interests. Public production focused on the vaccines that were required, even if their production was not cost-effective (e.g. BCG, DPT and viral vaccines), while private production focused on those that generated economic benefits. Public production entailed national technology, private production utilised imported technology. In the former, the research carried out created scientific and technological holdings that served the country, while in the latter most research took place outside Mexico and the benefits were accrued by parent industries. In public production, prices were set in relation to costs, unburdened by extra charges for attractive presentations and propaganda, while private production depended on supply and demand and their prices definitely included such charges. Public production assured that currency remained in Mexico, while private manufacturing increased capital flight. Public production concentrated on products that resolved local problems, which was of little or no concern to private production. In public production, all products were generated within the country, while private production required importing finished products or products shipped in bulk. In the public sector, the technical and administrative personnel were Mexican, in the private sector they were foreigners (with the exception of Myn y Zapata Laboratories). ${ }^{75}$

For all these reasons, Garza Ramos wrote that, 'National production of these goods constitutes a priority, since their acquisition in foreign markets is tremendously onerous, and doing without said products would bring as a consequence the deterioration of the population's health. ${ }^{76}$ Producing biologics in Mexico meant taking advantage of human and technological resources and of the installed capacity at both the National Institute of Hygiene and the National Institute of Virology of the General Management of Biologics and Reagents.

Mexican scientists also controlled the quality of imported vaccines that were not yet produced in the country: those for rubella, mumps, cholera, yellow fever (for people travelling abroad), a serum against coral snake venom (for high-risk zones), and the rabies vaccine elaborated with diploid cells. ${ }^{77}$ The government placed emphasis on national self-sufficiency in vaccine production, as well as on efforts to diagnose and control disease, especially those of greatest epidemiological importance.

In 1990, human and technological resources existed in the country, and both the National Institute of Hygiene and the National Institute 
of Virology had the capacity to produce, certify, store and distribute quality biological products in the required quantities in a timely fashion. In other words, self-sufficiency had been achieved. Since 1990, there have been no reported cases of unvaccinated poliomyelitis and since 1991 no cases of diphtheria. ${ }^{78}$

But things were already beginning to change. On the one hand, there was a high demand for biological products owing to the existence of ambitious vaccination programmes; vaccines were becoming more complex, and new ones were being developed. On the other hand, as in several other countries, there was also growing pressure from international industry (organised into ever more powerful consortiums), which had succeeded in lowering costs and improving quality. These were advances that the public sector could not achieve, in particular, because reduced budgets for health care came with the application of neo-liberal policies in the area of health services (this process is thoroughly analysed by Blume in Chapter 6 in this book). ${ }^{79}$ Private enterprises had begun to invest in vaccines and sera production: their 5.5 million peso investments in 1983 rose to 51 million in $1990{ }^{80}$ In 1989 , a period of 'expansion and confusion' - in Garza Ramos words - began, and it ended up diminishing the production of some fundamental biologics, and in its eventual disappearance. This signalled the beginning of the erosion of Mexican vaccine production. ${ }^{81}$

The General Direction of Biologics and Reagents and the Ministry of Health (renamed in 1985) decided to transform the institutes into a privatised industry. They began with Biomex - though this measure never surpassed the project phase - at great cost to the health administration. In 1991, Birmex, an entity mostly based on state-level participation, was created. Thereafter, Mexico suspended fabrication of most vaccines: BCG, measles, pertussis, diphtheria and tetanus for children, and rabies. BCG, for example, ceased to be produced domestically, because from one day to the next the Ministry of Health requested bottles with fewer dosages, which was impossible to achieve immediately. Today Mexico imports all these vaccines. Consequently, it had lost self-sufficiency in vaccine supply by the beginning of the new millennium. ${ }^{82}$ Some raised their voices against the new government policy - such as former head of the Institute of Hygiene, Manuel Servín Massieu - and many Mexican epidemiologists and scientists disagree with this loss, but they were unable to organise against it. 
Birmex only produces poliomyelitis and tetanus and diphtheria for adult vaccines, though it does market products from private enterprises. When the switch from OPV to IPV is complete, they will also stop producing the polio vaccine. Birmex's functionaries have participated in PAHO and WHO Good Manufacturing Programmes, which offer training and specialisation aimed at health authorities and the academic and industrial sectors. ${ }^{83}$

This later period has also seen changes in Mexico's routine vaccination schedule. In 1998, the number of vaccines on the schedule rose from six (Bacillus Calmette-Guérin [BCG], oral polio vaccine [OPV], diphtheria, pertussis and tetanus [DPT] and measles) to eight, as mumps and rubella were added. Then, in 1999 it increased to ten, with the addition of the $H$. influenzae $\mathrm{b}$ (Hib) and hepatitis B vaccines. In 2006 and 2007, respectively, pneumococcus and retrovirus vaccines were added. Since 2009, the human papilloma virus vaccine has been applied to 9-year-old girls. In 2000, authorities initiated programmes to vaccinate the adolescent and young adult population (measles, rubella, hepatitis B and influenza), those over 60 years of age (influenza, pneumococcus, diphtheria, tetanus and hepatitis B) and pregnant women (diphtheria, pertussis and tetanus). ${ }^{84}$

\section{Final reflections}

Since the early nineteenth century, vaccination in Mexico was a matter of state concern regarding public welfare (as in Brazil, discussed by Benchimol: Chapter 7 in this book), but it also reflected an elite concern with national security. In a country frequently beset with political violence, it is no coincidence that disease immunity was often considered an element of political strategy. Mexico had foreign enemies with a habit of invasion, and Mexican sanitary authorities always pointed out that vaccine production was as old as the production of ammunitions, meaning that both were needed to protect the Mexican people against their enemies.

In its dependence on foreign institutes and manufacturing laboratories for training and models of manufacture, and in its repeated stopping and starting of vaccine production under conditions of revolutionary instability, Mexico's experience anticipated, by at least fifty years, the similar difficulties that institutions of science and 
technology experienced in new countries in Asia and Africa following decolonisation.

The end of the nineteenth century saw the birth of modern public health and the production of public sector vaccine, which would be the start of a long tradition. Although separated by a decade of civil war, the government of Porfirio Díaz and the post-revolutionary governments formed part of the same process of capitalist development, and they all considered science to be congruent with their goals. The Díaz regime laid the foundations of modern public health, while postrevolutionary governments sought to make public health an integral part of nation-state formation. As a result, it became possible for the country to develop in its own individual path, with the support of advances in Europe and the United States.

Many of the researchers who worked in the production of vaccines studied in institutions abroad. Mexican scientists established many ties, regardless of the nationality of those who could train them. In the last third of the nineteenth century, several of them studied at French, German, and US institutions, and then introduced the bacteriological thinking and practices they learned there back at home; the main influence was the Pasteur Institute in France. By contrast, in the twentieth century the Rockefeller Foundation and the WHO exerted dominant influence.

This building of relationships with scientists from many countries brought the early introduction of the BCG, pertussis and polio vaccines. This was not a simple transfer of science to the periphery. The reception of new ideas and theories was active as Mexicans maintained direct contact with vanguard scientists through several means, including participation in congresses, personal correspondence and research exchange programmes; they also created institutes where they carried out original, basic and applied research. ${ }^{85}$

Between 1895 and 1905, Mexico founded the Anti-Rabies Preventive Inoculation Service, the National Pathology Institute and the National Bacteriology Institute, and they combined research with the production of vaccines and sera. The Civil War interrupted these works almost completely, but in 1920 they were reorganised and for the following five decades played a fundamental role in building and strengthening the nation. The years between 1921 and 1934 brought the first efforts at national reconstruction in Mexico, in which government 
policies regarding public education and health played an important role. The Mexican government was concerned with achieving levels of production that were sufficient to satisfy its immunisation programmes in the hope of assuring future healthy generations.

Over the course of the twentieth century, state builders created several institutions devoted to the production of vaccines: the Institute of Hygiene, the Laboratory of the Pharmaceutical Industry, the National Institute of Virology and the Central Laboratory of Reagents, all attached to the Ministry of Health. They considered that national production of vaccines and sera were not only a matter of national pride, but also a priority, because of the high costs of importing them, because they were needed to protect the population and to help lower morbidity and mortality due to infectious diseases, and last but not least, for reasons of national security, namely to assure the availability of biological products in order to avoid the economic and technical dependence that came with imported products and the transfer of foreign methodologies. ${ }^{86}$

Today, this development has practically disappeared; though this was no linear history, as this chapter has sought to demonstrate, and in the past there were cases of what Marcos Cueto has called scientific excellence in the periphery. ${ }^{87}$ Indeed, it was not intellectual or technical incapacity that influenced the disappearance of national vaccine production but rather economic, political and cultural factors, including strong governments, revolution and civil war, controversies among physicians, rebellions against vaccines, accidents, and the creation, reorganisation and dissolution of institutions. As Saldaña would say, these were particular experiences of science, which turned out as they did due to their local history; one manifestation, among many others, of Mexican science thinking on its own.

\section{Acknowledgements}

I am grateful to Stuart Blume for his perseverance in conducting collective research on the history of vaccines and vaccination around the world, and to Blume, Christine Holmberg and Paul Greenough for their invitation to write this chapter, as well as for their critiques and extremely helpful suggestions. I also benefited from the advice of Elizabeth O'Brien. 


\section{Notes}

1 J.J. Saldaña, Las revoluciones políticas y la ciencia en México [Political revolutions and science in Mexico], 2 vols (Mexico, Conacyt, 2010), 1, pp. 32-7.

2 The vaccine had been brought to Puerto Rico from the Danish island of Saint Thomas. The arrival in Cuba of a woman who had recently been vaccinated in Puerto Rico led the professor of medicine Tomás Romay to begin vaccination on the island. The fluid had also arrived in New Spain, carried by two ships coming from La Habana. Díaz de Iraola, G ... La vuelta al mundo de la Expedición de la Vacuna (1803-1818) [The Round the World Voyage of the Smallpox Vaccine (1803-1818)] (Spain: Consejo Superior de Investigaciones Científicas/Escuela de Estudios HispanoAmericanos de Sevilla, 1948).

3 M. E. Bustamante, 'Consecuencias médico-sociales de la viruela y de su erradicación' [Socio-medical Consequences of Smallpox and its Eradication], Gaceta Médica de México, 113 (1977), pp. 564-73.

4 D. Tank-de-Estrada, 'Justas florales de los botánicos ilustrados. Ciencia y tecnología en la historia de México' [Public Contests of the Enlightened Botanists. Science and Technology in Mexican history], Diálogos, 106 (1989), pp. 19-31; J. J. Saldaña, 'Acerca de la historia en la ciencia nacional' [Regarding History in National Science], in J. J. Saldaña (ed.), Los orígenes de la ciencia nacional [The Origins of National Science] (México: Universidad Nacional Autónoma de México/Sociedad Latinoamericana de Historia de las Ciencias y la Tecnología, 1992), pp. 9-54.

5 J. M. Oropeza, 'Apuntes para la historia de la vacuna en México' [Notes for the History of the Vaccine in Mexico], Archivo Histórico de la Secretaría de Salud, México [Historical Archive of the Ministry of Health, Mexico] (hereafter, AHSSA), salubridad pública [Public Health], Inspección de la Vacuna [Vaccine Inspection], 3/ 20, f. 49-182, 1921-2.

6 Ibid.

7 J. Álvarez-Amézquita, M. E. Bustamante, A. López-Picazos and F. Fernández-del Castillo, Historia de la salubridad y de la asistencia en México [History of Health and Welfare in Mexico], 4 vols (México: Secretaría de Salubridad y Asistencia, 1960), 2.

8 A. M. Carrillo, 'Por voluntad o por fuerza. La lucha contra la viruela en el porfirismo' [Voluntary or by Force. The Fight Against Smallpox During Porfirian Times], in C. Cramaussel and M. A. Magaña-Mancillas (eds), El impacto demográfico de la viruela en México de la época colonial al siglo XX. La viruela después de la introducción de la vacuna [The demographic impact of smallpox from colonial times to the 20th century. Smallpox after vaccine introduction], 3 vols (Zamora: El Colegio de Michoacán, 2010), pp. 91-111. 
9 A. M. Stern and H. Markel, 'The History of Vaccines and Immunization: Familiar Patterns, New Challenge', Health Affairs, 24:1 (2003), pp. $611-21$.

10 Gobierno del Estado de Oaxaca, Historia de la salud en Oaxaca [History of Health in Oaxaca] (Oaxaca: Gobierno del Estado de Oaxaca, 1993).

11 A. C. Rodríguez de Romo, 'La ciencia pasteuriana a través de la vacuna antirrábica: el caso mexicano' [Pasteurian Science Through the Rabies Vaccine: The Mexican Case], Dynamis, 16 (1996), pp. 291-316.

12 A. Reyes, 'Inoculaciones preventivas de la rabia' [Preventive Rabies Vaccine], Gaceta Médica de México, 24:18 (1889), pp. 344-7.

13 E. Liceaga, Algunas consideraciones acerca de la higiene social en México [Some reflections about social hygiene in Mexico] (México: Vda. de F. Díaz de León, 1911).

14 Archivo Histórico de la Universidad Nacional Autónoma de México [Historical Archive of the National Autonomous University of Mexico], Escuela Nacional de Medicina [National School of Medicine], institutos y sociedades médicos [Medical Institutes and Societies], Museo AnatomoPatológico-Instituto Patológico Nacional [Pathological Anatomy Museum-National Pathology Institute], 40/1, f. 1v, 1895.

15 A. M. Carrillo, '¿Estado de peste o estado de sitio? Mazatlán y Baja California 1902-1903' [State of Plague or State of Siege? Mazatlan and Baja California, 1902-1903], Historia Mexicana, 54:4 (2005), pp. 1049-103.

16 Archivo Histórico de la Secretaría de Relaciones Exteriores, México [Historical Archive of the Secretary of Foreign Affairs, Mexico], Embajada de México en los Estados Unidos de América [Mexican Embassy in the United States of America], 164/4, 115 f.: 46-7, 1900-4 and 1907-8.

17 I. J. Catanach, 'Plague and the Tensions of the Empire 1988: India 18961918', in D. Arnold (ed.), Imperial Medicine and Indigenous Societies (Manchester: Manchester University Press, 1988), pp. 149-71.

18 'Ley constitutiva del Instituto Patológico Nacional y del Instituto Bacteriológico Nacional' [Constitutive Law of the National Pathology Institute and the National Bacteriology Institute], Diario Oficial [Official Gazette] (ciudad de México, 17 October 1905), pp. 629-31; M. Servín-Massieu, Microbiología, vacunas y el rezago científico de México a partir del siglo XIX [Microbiology, vaccines and scientific lag in Mexico from the 19th century on] (Mexico: Instituto Politécnico Nacional/Plaza y Valdés, 2000).

19 A. M. Carrillo, 'La patología del siglo XIX y los institutos nacionales de investigación médica en México' [19th Century Pathology and the National Medical Research Institutes in Mexico], Laborat-ACTA, 13:1 (2001), pp. 23-31. 
20 A. Garza-Brito, 'El Instituto Nacional de Higiene' [The National Institute of Hygiene], AHSSA, Instituto de Higiene [Institute of Hygiene], trabajos de concurso [professional concourse], 2/22 [88f.], 1989.

21 Álvarez-Amézquita et al., Historia de la salubridad.

22 A. M. Carrillo and A. E. Birn, 'Neighbors on Notice: National and Imperialist Interests in the American Public Health Association', Canadian Bulletin of Medical History/Bulletin Canadien d'histoire de la Medicine, 25:1 (2008), pp. 225-54.

23 Servín-Massieu, Microbiología, vacunas..

24 Archivo Histórico de la Facultad de Medicina de la Universidad Nacional Autónoma de México [Historical Archive of the Faculty of Medicine of the National Autonomous University of Mexico], Escuela de Medicina y Alumnos [School of Medicine and Students], 204/19, $38 \mathrm{f}$.

25 R. Silva, 'Muerte del socio honorario D. Manuel Toussaint' [Death of the Honorary Member D. Manuel Toussaint], Gaceta Médica de México, 58:12 (1927), pp. 787-90.

26 AHSSA, salubridad pública, expedientes de personal [staff records], 35/1, 2 and 3; 113, 220 and 167 f.; 1896-1900, 1900-7 and 1907-29.

27 Gaceta Médica de México, 5:5 (1910), p. 187.

28 I. Costero, 'Desarrollo de la anatomía patológica en México' [Development of Pathological Anatomy in Mexico], in E. Beltrán (ed.), Memorias del I Coloquio de Historia de la Ciencia [Proceedings of the History of Science Symposium] (México: Sociedad Mexicana de Historia de la Ciencia y la Tecnología, 1964), pp. 349-69.

29 A. M. Carrillo, 'La influencia de la bacteriología francesa en la mexicana en el periodo de su institucionalización' [The Influence of French Bacteriology on Mexican Bacteriology in the Period of its Institutionalisation], Quipu. Revista Latinoamericana de Historia de las Ciencias y la Tecnología, 14:2 (2012), pp. 93-119.

30 A. De-Garay, 'En memoria del Dr. Ángel Gaviño' [In memory of Ángel Gaviño], Salud Pública de México, 2:4 (1960), pp. 899-903.

31 A. E. Birn, Marriage of Convenience. Rockefeller International Health and Revolutionary Mexico (Rochester: University of Rochester Press, 2006).

32 J. Garza-Ramos, C. Viesca and G. Franco-de-Guzmán, 'Les vaccins au Mexique' [Vaccines in Mexico], in J. Garza-Ramos (ed.), Symposium. Progres a l'usage de vaccins, 1885-1985 [Symposium. Progress in the Use of Vaccines, 1885-1985] (México: Gerencia General de Biológicos y Reactivos/Secretaría de Salud, 1986), pp. 260-9.

33 A. M. Moulin, 'The International Network of the Pasteur Institute: Scientific Innovations and French Tropisms', in C. Charle, J. Schriewer and P. Wagner (eds), The Emergence of Transnational Intellectual Networks and the 
Cultural Logic of Nations (New York: Campus Verlag, 2004), pp. $135-62$.

34 A. Pérez-Miravete, 'La producción mexicana de reactivos y vacunas' [Mexican Production of Reagents and Vaccines], in M. Urbina-Fuentes, A. Moguel-Ancheita, M. Muñiz-Martelón and J. A. Solís-Urdaibay (eds), La experiencia mexicana en salud pública. Oportunidad y rumbo para el tercer milenio [The Mexican Experience in Public Health. Opportunity and Direction for the Third Millennium] (Mexico: Secretaría de Salud/Organización Panamericana de la Salud/Sociedad Mexicana de Salud Pública/Fundación Mexicana para la Salud/Instituto Nacional de Salud Pública/Fondo de Cultura Económica, 2006), pp. 177-89.

35 H. Zinsser and M. R. Castaneda, 'Mexican Typhus Fever', Journal of Experimental Medicine, 57:3 (1933), pp. 381-90.

36 Birn, Marriage of Convenience.

37 Seis años de gobierno al servicio de México 1934-1940 [Six Years of Government Service to Mexico 1934-1940] (Ciudad de México: Talleres Gráficos de la Nación, 1940). R. Vargas-Olvera, 'Introducción', in Y. Trejo, R. Vargas-Olvera, D. Molina-Alamilla et al., Guía del Fondo del Instituto de Salubridad y Enfermedades Tropicales [Guide of the Institute of Public Health and Tropical Diseases Collection] (México: Secretaría de Salubridad y Asistencia, 1993), pp. i-xii.

38 AHSSA, Instituto de Higiene, trabajos de concurso, 2/22 [88ff.], 1989.

39 E. Landa, 'Las primeras aplicaciones del suero antitifoso de Ruiz Castañeda y Zinsser' [The First Applications of the Ruiz Castañeda and Zinsser Anti-Typhus Serum], Gaceta Médica de México, 66:3 (1933), pp. $123-32$.

40 T. Taylor, 'The Doctor's Trial and the Nuremberg Code. Opening Statement of the Prosecution, December 9, 1946', in G. J. Annas and M. A. Grodin (eds), The Nazi Doctors and the Nuremberg Code: Human Rights in Human Experimentation (New York: Oxford University Press, 1992), pp. 67-93.

41 Garza-Ramos, Viesca and Franco-de-Guzmán, 'Les vaccins au Mexique'.

42 C. G. Shapiro-Shapin, 'Pearl Kendrik, Grace Eldering, and the Pertussis Vaccine', Emerging Infectious Diseases, 18:8 (2010), pp. 1273-8.

43 A. De-la-Garza Brito, 'El Instituto Nacional de Higiene', AHSSA, Instituto de Higiene, trabajos de concurso, 2/22 [88 f.], 1989.

44 Silvermann, quoted in Pérez-Miravete, 'La producción mexicana de reactivos y vacunas'.

45 AHSSA, Instituto de Higiene, trabajos de concurso, 2/22 [88f.], 1989.

46 A. M. Carrillo, 'Salud pública y poder en México durante el Cardenismo, 1934-1940' [Public Health and Power in Mexico During Cárdenas’ Times, 
1934-1940], Dynamis, 25 (2005), pp. 145-78: Birn, Marriage of Convenience.

47 Garza-Ramos, Viesc and Franco-de-Guzmán, 'Les vaccins au Mexique'.

48 AHSSA, Secretaría de Salubridad y Asistencia [Ministry of Public Health and Welfare], Gerencia General de Biológicos y Reactivos [General Management of Biological Products], 20/8, 270 f., 1982.

49 AHSSA, Secretaría de Salubridad y Asistencia, Subsecretaría de Asistencia [Underministry of Welfare], 53/1, $248 \mathrm{f}$. [n.fol.n], 1950-79.

50 Ibid.

51 AHSSA, Secretaría de Salubridad y Asistencia, 13/ 5, 232 f., 1946-80.

52 Garza-Ramos, Viesca and Franco-de-Guzmán, 'Les vaccins au Mexique'.

53 Ibid.

54 Diario Oficial, Mexico, 27 April 1953, p. 1.

55 F. Gómez, 'Symposium sobre examen de los conocimientos actuales sobre vacunación en la poliomielitis. Introducción' [Symposium on Current Knowledge About Poliomyelitis Vaccination], Gaceta Médica de México, 91:12 (1961), pp. 1051-3.

56 L. Gutiérrez-Villegas, 'Resultados de la vacuna contra la poliomielitis tipo Salk elaborada en México' [Results of the Poliomyelitis Salk Vaccine Produced in Mexico], Gaceta Médica de México, 88:5 (1958), pp. 82-93.

57 J. Muñoz-Turnbull, 'Observaciones sobre la vacuna antipoliomielítica preparada en México. Conocimientos recientes sobre su aplicación' [Observations Regarding the Poliomyelitis Vaccine Produced in Mexico. Recent Knowledge About its Application], Gaceta Médica de México, 87:5 (1957), pp. 337-44.

58 Gutiérrez-Villegas, 'Resultados de la vacuna contra la poliomielitis tipo Salk elaborada en México'.

59 'Carta del Comité Nacional de Lucha contra la Poliomielitis al ministro de la Secretaría de Salubridad y Asistencia' [Letter from the National Committee for the Fight against Poliomyelitis to the Minister of Health and Welfare], Mexico, 30 April 1954, AHSSA, Secretaría de Salubridad y Asistencia, Secretario Particular [Particular Secretary], 95/ 1, $186 \mathrm{f}$.

60 S. Blume, 'Lock in, the State and Vaccine Development: Lessons from the History of Polio Vaccines', Research Policy, 34 (2005), pp. 159-73.

61 C. Calderón and C. Campillo, 'Epidemiología de la poliomielitis en México. Mecanismos de inmunización' [Epidemiology of poliomyelitis in Mexico. Immunisation mechanisms], Boletín Epidemiológico [Epidemiological Bulletin], 24:4 (1960), pp. 117-25.

62 AHSSA, Secretaría de Salubridad y Asistencia, Subsecretaría de Salubridad [Underministry of Health], caja 38, exp. 1, 313 f., 1979. 
63 J. I. Santos, 'Cambios en los esquemas de vacunación y la vacunación en adultos' [Changes in Vaccination Schedule and in Adult Vaccination], in M. Urbina-Fuentes, A. Moguel-Ancheita, M. Muñiz-Martelón and J. A. Solís-Urdaibay (eds), La experiencia mexicana en salud pública. Oportunidad y rumbo para el tercer milenio (México: Secretaría de Salud/Organización Panamericana de la Salud/Sociedad Mexicana de Salud Pública/Fundación Mexicana para la Salud/Instituto Nacional de Salud Pública/Fondo de Cultura Económica, 2006), pp. 191-223.

64 U. Lindner and D. Blume, 'Vaccine Innovation and Adoption: Polio Vaccines in the UK, the Netherlands and West Germany, 1955-1965', Medical History, 50 (2006), pp. 425-46.

65 A. Escobar, J. L. Valdespino and J. Sepúlveda, quoted in Pérez-Miravete, 'La producción mexicana de reactivos y vacunas'.

66 O. L. Galicia Aguilar, 'Un accidente doloroso' [A painful accident]: PérezMiravete, 'La producción mexicana de reactivos y vacunas'.

67 AHSSA, Secretaría de Salubridad y Asistencia, Gerencia General de Biológicos y Reactivos, 2/4, 280 f., 1965-70.

68 AHSSA, Secretaría de Salubridad y Asistencia, Gerencia General de Biológicos y Reactivos, 10/6, 148 f, 1970; 12/3, 158 f., 1970-71; 19/1, 239 f., 1980-81, 20/8, 380 f., 1982: Pérez-Miravete, 'La producción mexicana de reactivos y vacunas'. AHSSA, Instituto de Higiene, trabajos de concurso, 2/22, 88 f., 1989.

69 Interview with Juan Garza Ramos, Director of the General Management of Biologics and Reagents between 1983 and 1988, and now Director of the National Producer of Veterinarian Biologics (conducted by the author, Mexico City, March 2014).

70 A. Garza-Brito,'El Instituto Nacional de Higiene', AHSSA, Instituto de Higiene, trabajos de concurso, 2/22 [88 f.], 1989.

71 A. Homma, J. L. di Fabio and C. de Quadros, 'Los laboratorios públicos productores de vacunas: el nuevo paradigma' [Public Laboratories for Vaccine Production: A New Paradigm], Revista Panamericana de Salud Pública [Pan American Journal of Public Health], 4:4 (1998), pp. 223-32, www.scielosp.org/scielo.php?script=sci_arttext\&pid=S102049891998001000001 (accessed 31 August 2016).

72 J. Garza-Ramos, 'La producción de biológicos y reactivos en México', AHSSA, Instituto de Higiene, trabajos de concurso, 2/22 [88 f.], 1989.

73 Interview with Juan Garza Ramos (conducted by the author, Mexico City, March 2014).

74 Pérez-Miravete, 'La producción mexicana de reactivos y vacunas'. AHSSA, Instituto de Higiene, trabajos de concurso, 2/22 [88 f.], 1989. 
75 AHSSA, Secretaría de Salubridad y Asistencia, Gerencia General de Biológicos y Reactivos, 17/6, 219 f., 1977-1978.

76 Garza-Ramos, 'La producción de biológicos y reactivos en México', AHSSA, Instituto de Higiene, trabajos de concurso, 2/22 [88 f.], 1989.

77 Ibid.

78 AHSSA, Secretaría de Salubridad y Asistencia, Gerencia General de Biológicos y Reactivos, 17/ 6, 219 f., 1977-78.

79 S. Blume, J. Jagrati and S. Roalkvam, 'Saving Children's Lives: Perspectives on Immunisation', in S. Roalkvam, D. McNeill and S. Blume (eds), Protecting the World's Children. Immunisation Policies and Practices (Oxford: Oxford University Press, 2013), pp. 1-30.

80 Garza-Ramos, 'La producción de biológicos y reactivos en México'.

81 Interview with Juan Garza-Ramos (conducted by the author, Mexico City, March 2014).

82 Pérez-Miravete, 'La producción mexicana de reactivos y vacunas'.

83 www.paho.org/HQ/index.php?option=com_content\&view=article\& id $=1589 \% 3$ Agrupo-de-trabajo-en-buenas-pruecticas-de-manufactura \& catid $=1157 \% 3$ Ahss-pandrh-technical-working-grou\&Itemid= 1686\&lang=en (accessed 15 September 2013).

84 http://web.ssaver.gob.mx/saludpublica/files/2014/02/mensajeroSNSalud.pdf (accessed 20 October 2014).

85 F. T. Glick, 'La transferencia de las revoluciones científicas a través de las fronteras culturales' [The Transfer of Scientific Revolutions Through Cultural Boundaries], Ciencia y Tecnología, 12:72 (1987), 77-89.

86 AHSSA, Secretaria de Salubridad y Asistencia, Subsecretaria de Asistencia, 13/5, 232 f., 1946-80.

87 M. Cueto, Excelencia cientifica en la periferia [Scientific Excellence in the Periphery] (Perú: GRADE CONCYTEC, 1989). 